\title{
THE POSITION OF THE DECADENT NOVEL WITHIN ROMANIAN FIN-DE-SIÈCLE LITERATURE
}

\author{
The Late $19^{\text {th }}$-Century Romanian Novel
}

In $1903 \mathrm{Th}$. Cornel produced an inventory of Romanian literature in general and of the Romanian novel in particular in his French-language book-length study La Roumanie littéraire d'aujourd'hui. There were precious few such surveys, not due to the abundance of the literary material to be surveyed, but, on the contrary, due to its paucity. This is also what three decades before had been noted by one of the founders of Romanian literary criticism and the father of the first Romanian literary canon, Titu Maiorescu, both leader of Junimea, the important literary movement with a well-defined programme, and a towering politician as a member of the Conservative Party. Titu Maiorescu first published a survey of Romanian poetry, O cercetare critică asupra poeziei române [A Critical Study of Romanian Poetry], in 1867, with a new edition in 1892 . Then, in 1872, he shifted his attention to Romanian prose in his Direcția nouă în poezia și proza română [The New Direction of Romanian Poetry and Prose]. It is striking that Maiorescu noted the absence of a literary genre, the novel, alongside the short story, seemingly compensated for by translations: "We have no literary activity and characteristically - no novels and short stories are written, but only translated"1. His radical statement thus dismissed all Romanian novels written earlier, among which Nicolae Filimon's Ciocoii vechi și noi [Fleecers Old and New] (1863), Dimitrie Bolintineanu's Manoil (1855) and Elena (1862), Radu Ionescu's Catastihul amoriului și La gura sobei [Love's Books and By the Fireplace] (1865) - to mention only novels proper and leaving aside romances.

We might object that such production is meagre enough, yet such paucity becomes truly significant if we regard its background, the process of rapid edification of a national literature almost ex nihilo since the latter half of the $19^{\text {th }}$ century, when new literary genres were introduced and when the playwrights, novelists and essayists first started publishing in the Romanian language. Could Titu Maiorescu have missed the debut of the novel, however modest, in Romanian literature? May the respective novelists have been dismissed because they were not Junimea members? Anyway, beyond any bias on Maiorescu's part, it should be mentioned that the novel of the time lacked both the coagulating generative force and the prestige of poetry to make much of an impression on Maiorescu and therefore be included in any "direction" contemplated by the Jumimea critic, so as

\footnotetext{
${ }^{1}$ Titu Maiorescu, Critice [Critical Studies], București - Chișinău, Litera, [s.a.], p. 160.
} 
to be able to foster emulation within the fin-de-siècle literary movement. For Titu Maiorescu, prose can be either non-fictional - wherein he included literary criticism and thus the writings of Alexandru Odobescu, Ion Strat, Ioan Slavici, Alexandru D. Xenopol, Vasile Burlă, Teodor Vârgolici, Constantin Negruzzi, Gheorghe Panu, Alexandru Lambrior, Petre P.Carp, Theodor Rosetti - or aesthetic. The latter encompassed very few works: The Imitations of Nature [Copiile de pe natură] by Iacob Negruzzi, the Historical Short Stories [Nuvelele istorice] by A. Odobescu, the studies of Messrs Vârgolici and Lambrior, the Short Stories [Nuvelele] by Mr Nicu Gane"2. While Titu Maiorescu was hardly inclined to analyse prose, he would dedicate separate studies, however, to an outstanding poet, Mihai Eminescu, to a major playwright, I.L. Caragiale, and to a promising prose writer, Mihail Sadoveanu. At stake was not literature proper, but literary language in relation to the Romanian language at one point in time during its formalization process, which explains Maiorescu's intense polemic with the Transylvanian philological school - Junimea's adversary - which had its own project of reforming the Romanian language. To state it otherwise, literature became the arena of a confrontation regarding the edification of the Romanian language - a major argument in this querelle within the ranks of the Romanian literati at the end of the $19^{\text {th }}$ century. The aesthetic assessment of literature concerned at this point the assessment of the Romanian language it used and thus disseminated as a model, of the neological load which it locked in and metabolised. One further detail: Titu Maiorescu published his studies in Romanian because he did not aim at a foreign readership, as the highly polemical character of his studies also indicates.

By contrast, for Th. Cornel, what was at stake was to produce a picture of Romanian literature, of its aesthetic accomplishments, for an educated Romanian readership - at a time when education entailed knowing French - as well as for foreign readers interested in exotic literatures. Jules Michelet had been drawn to our folk literature thanks to the French translations produced by Vasile Alecsandri.

Yet, with regard to the Romanian novel, there was little to commend it even in 1903, when Th. Cornel highlighted what he considered noteworthy. Yet, not a word did he mention about the mystery novels of Ioan M. Bujoreanu, George Baronzi, C.D. Aricescu, I.P. Valerianu, nor about the hajduk novels penned mostly by the indefatigable N.D. Popescu ${ }^{3}$, or about the historical romances of Al. Pelimon. $19^{\text {th }}$-century Romanian paraliterature was to a great extent its literature too and engendered wide consensus among its readership. Writers encoded in the "original novel" phrase appended to the title which was at stake at the time, namely the introduction of the new literary genre with a Romanian topic, within a Romanian context. Th. Cornel mentioned a few accomplishments such as

\footnotetext{
${ }^{2}$ Ibidem, p.176.

${ }^{3}$ On the hajduk novel as a subgenre see Roxana Patraș, "Hajduk Novels in Nineteenth-Century Romanian Culture: Notes on a Sub-Genre", Swedish Journal of Romanian Studies, 2, 2019, 1, http://www.diacronia.ro/ro/indexing/details/A30120/pdf. Accessed December 15, 2020.
} 
Vlahuță's Dan (1894), which he commended for its "pages de fine psychologie", Duiliu Zamfirescu's Viața la țară [Life in the Countryside] (1898), which depicts a scene of the dissolution of local gentry, V. Crăsescu's Ovreiul [The Yid] (1893), Const. Mille's Dinu Millian (1887), Traian Demetrescu's Iubita [The Beloved] (1895), which Th. Cornel somewhat dismissed by employing "plutôt en amateur de sensations nouvelles" as a taste differential too, Spiru Prasin's Calea robilor [The Way of Slavery] (1903), as well as I. Adam's novels of 1902, Rătăcire [Lost] and Sybaris, which Th. Cornel described as "deux romans à thèse, victimes d'une phraséologie accablante"4. Th. Cornel's was a fine survey of the Romanian novel scene; it nevertheless excluded the fashionable mystery novel and hajduk novel, but also, in part, the decadent novel, which depicted the fin-de-siècle issues in a modernist key.

This new modernist sensibility was already apparent in the symbolist poetry which poet and prose-writer Alexandru Macedonski introduced to the circle and literary magazine Literatorul, which he chaired himself. Th. Cornel himself noted this selfsame sensibility in both Traian Demetrescu and Ion Adam, which he labelled rather derisively as "sensations nouvelles", and the style of "phraséologie accablante". Nonetheless, insofar as he was familiar with French literature, Th. Cornel may have known the plentiful French literary output with decadent topics, however minor, yet highly praised by a public thirsty for "novel sensations". The decadent novel was immensely popular in France around 1900, particularly thanks to J.-K. Huysmans' emblematic novel $\dot{A}$ Rebours (1884), but also to a minor, if tremendously prolific and popular novelist, Josèphin Péladan. The latter had visited Romania at the invitation of Alexandru Bogdan-Pitești, an outstanding Maecenas favourable to modernity, whose "face" (in Matei Calinescu's terms) in the age was represented equally by decadence and symbolism. Josèphin Péladan's conference at the Athenee on 30 January 1898, which had raised a public scandal with a few provoking remarks, was a seminal influence on both Macedonski's symbolist circle and on the Romanian Secessionist artists involved with the Tinerimea artistică ${ }^{5}$.

We must note here a similarity with symbolist poetry, namely the fact that the reception of symbolist-decadent poetry began with minor poets such as Maurice Rollinat or Albert Samain, whose work allowed the subsequent adaptation of taste to a superior aesthetic canon such as that represented by Rimbaud, Baudelaire, Verlaine or Mallarmé. Nonetheless, both these aesthetic levels - the decadent masterpiece and the numberless decadent novels that share thematic concerns were familiar to an exclusivist public at the end of the $19^{\text {th }}$ century. Quite tellingly, Joséphin Péladan's first novel, Le vice suprême, illustrated by the symbolist

\footnotetext{
${ }^{4}$ Th. Cornel, La Roumanie littéraire d'aujourd'hui, Paris, E. Sansot et Cie, 1903, pp. 24, 25.

${ }^{5}$ For details see Angelo Mitchievici, "Joséphin Péladan și decadența latină" ["Joséphin Péladan and Latin Decadence"], in Decadență și decadentism în contextul modernității române și europene [Decadence and Decadentism within Romanian and European Modernity], București, Curtea-Veche, 2011, pp. 321-337.
} 
Belgian painter Félicien Rops, was published in the same year - 1884 - as K.-J. Huysmans' À Rebours, and the author intended nothing more or less - in fact, he published as many as nineteen novels - than to create a human comedy of decadent sensibility and thus rival Balzac himself: "C'est le titre de la grande entreprise romanesque de Péladan (La Décadence Latine), qui voulait être pour la France de 1880 ce que la Comédie Humaine fut pour celle de 1830"6.

\section{Decadence and Modernism: the Dynamics of Transition}

Despite its popularity, the decadent novel is far from being popular, as Jean de Palacio aptly remarks in his Figures et formes de la décadence, due to its erudition - the recourse to the cultural metatext being the earmark of decadence -, its cultivation of style, its artistic writing, its transgression of sexual taboos, in what Krafft-Ebing famously inventoried in his 1886 study as psychophatia sexualis ${ }^{7}$ :

La Décadence est une littérature d'abord difficile. L'espérer jamais populaire serait commetre un non-sens. Elle oppose au lecteur le barrage de son érudition, de son écriture et des ses silences. Pour être porteuese de scandale et dénuée de reconfort, elle inspire toujours la méfiance et la gêne ${ }^{8}$.

Late $19^{\text {th }}$-century French literature produced a genuine "bibliothèque décadente", as Jean de Palacio names the collection he supervises, which rescues from oblivion writers such as Jean Lorrain, Félicien Champsaur, Catulle Mendès, Camille Lemonnier, Jules Bois, Pierre Louÿs, Jean Richepin, Jane de la Vaudère, Leon Bloy, Paul Adam, Paul Alexis, Adolphe Belot, René Maizeroy, Michel Corday, Edmond Deschaumes, Fortuné du Boigobey, Jean Rameau, Maxime Formont, etc. The French comparativist argues, with regard to the aesthetic relevance of decadent literature, that (1) it was highly popular with the readers in its heyday; though now forgotten, its highly fashionable practitioners influenced public taste, thereby also modelling lifestyles in the age; (2) it represents a "precieux magasin d'images et de signes", or, in other words, it depicts a number of features of fin-de-siècle French culture; and (3) it has made a significant aesthetic contribution not only to style, but also to literary ideas in terms of experimentation rendered as hybridity, a feature which premodernity shared with modernity. Furthermore, certain symbolist, naturalist and realist writers such as Mallarmé, Verlaine, Huysmans, Mirbeau and Flaubert, according to Jean de Palacio, shared a decadent sensibility apparent in their works.

\footnotetext{
${ }^{6}$ Jean de Palacio, Figures et formes de la décadence, Paris, Séguier, 1994, p. 19.

7 See Richard von Krafft-Ebing, Psychopathia Sexualis. Translated by René Lobstein. Preface by Pierre Janet, Paris, Payot, 1931.

${ }^{8}$ Jean de Palacio, Figures et formes de la décadence, p. 11.

${ }^{9}$ Ibidem, p. 14.
} 
At the beginning of the $20^{\text {th }}$ century, including during the interwar period, some of these decadent writers who enjoyed wide popularity would also be translated into Romanian. Some such cases are quite telling ${ }^{10}$ : Jean Lorrain, Aventuri princiare [Princely Adventures], Pierre Louÿs, Aphrodita. Roman de moravuri antice (1928, a translation of Aphrodite: mours antiques, 1896) in two editions, Femeia și paiața. Roman din viața spaniolă (1931, a translation of La Femme et le pantin, 1898), a novel emblematic of decadent fiction, in two editions, O voluptate nouă (1923, a translation of Une volupté nouvelle, 1899); Oscar Wilde, Crimă şi conștiință (1920, a translation of The Portrait of Dorian Grey, whose Romanian title freely adapts the original $)^{11}$; Catulle Mendès, Frumoasa cu inema de zăpadă. Copilul găsit, Nuvele [The Frozen Heart Beauty. The Found Child. Short Stories](1913), Romanul roșu (1912, a translation of Le Roman rouge, around 1880), Tânăra căsătorită (a translation of Monstres Parisiens), second edition, again emblematic of decadence; Alfred Delvau, La poarta raiului (1899, a translation of À la porte du paradis, 1867); Gabriele D'Annunzio, Cartea fecioarelor. Nuvele [Short Stories] (1911, a translation of Il libro delle vergini, 1884), In lipsa lui Valer, Martirul, short stories (1910, a likely translation of Nell'assenza di Lanciotto, 1892, and Il martirio di San Sebastiano, written between 1910 and 1911), Nuvele [Short Stories] (1909), Pământ virgin. Nuvele și schițe (1914, a translation of Terra vergine), Tragedia a două fecioare; Félicién Champsaur, Mesalina. Orgia latină. Pentalogie biblical ilustrată (1921, a translation of Mesalina; L'Orgie latine), in three editions, virtually a best seller in the age; Prosper Castanier, Nuvele antice. Moravuri din timpul decadenței romane (1899, probably a translation of L'Orgie Romaine, 1897).

In his Influenţa franceză asupra spiritului public în România. Originile. Studiu asupra stării societăţii românești în vremea domniilor fanariote [The French Influence on the Public Spirit in Romania - the Origins: A Study of the Condition of Romanian Society under the Phanariot Rulers], Pompiliu Eliade ${ }^{12}$ has documented an ample phenomenon of acculturation, of voluntary assimilation of French culture and civilisation, first by the Romanian elites and subsequently by various groups (as a function of educational background) in the second half of the $19^{\text {th }}$ century. Thus, we can see that the yardstick of average education in the latter

\footnotetext{
${ }^{10}$ I have selected exclusively prose texts; however, among the translated texts are also poetry or drama by certain representative decadent prose writers such as Belgian poet and dramatist Maurice Maeterlinck, very fashionable in Romania in the interwar period. Where I have failed to mention the publication year of the Romanian translation, this is due to the data available in print. Many of these translations circulated as broadsheets without much editorial lustre, which also indicates their popular character and their wide dissemination in the form of instalments.

${ }^{11}$ Virtually all Oscar Wilde's works are translated into Romanian.

12 Pompiliu Eliade, Influenţa franceză asupra spiritului public în România. Originile. Studiu asupra stării societăţii româneşti în vremea domniilor fanariote [The French Influence on the Public Spirit in Romania - the Origins: A Study of the Condition of Romanian Society under the Phanariot Rulers], București, Editura Institutului Cultural Român, 2006.
} 
half of the $19^{\text {th }}$ century entailed mandatory knowledge of French. Many works of the decadent writers were read in the French original, as can be glimpsed from the quotations in the cultural magazines, as well as from the intertextuality of various literary works, which traces not only a complex network of affinities, but also one regarding the circulation and dissemination of literary ideas and models. Mateiu I. Caragiale, one of the decadent novelists of the interwar period, provides evidence of the Romanian taste for decadence. His correspondence with N. A. Boicescu at a crucial time for the former's cultural formation includes references to his youth readings, where pride of place is enjoyed by decadent novels and short stories by Barbey d'Aurevilly, Remy de Gourmont, Jean Lorrain, Félicién Champsaur, Paul Hervieu, Maurice Maindron and others. In effect, a decadent novel is often identifiable also by its focus on its elective affinity, as its characters pride themselves on their literary and aesthetic tastes in a symbolic gesture of coordinating their tastes with what they read or admire in the arts. Romanian literature would be strewn with decadent pieces as late as 1947, when all "decadent" writers were prohibited and any aestheticism in literature was stigmatised ideologically as decadent.

Echoes of Huysmans's novel can be found everywhere in Europe: in the UK, in Oscar Wilde's only novel, The Portrait of Dorian Gray, as the intertext, allusions and affinities demonstrate; in Italy, in Gabriele D'Annunzio's decadent novel Il Piacere (1889), where the systematic use of pastiche has raised the spectre of plagiarism accusations; and in Romania, in the novel Suflete obosite [Exhausted Souls] (1898) by Constantin I.A. Nottara, a writer whom Th. Cornel never mentions. Another novel, De vânzare [For Sale] (1896), anticipated the new decadent sensibility through its preoccupation with the major themes of decadence.

What is noteworthy with regard to Romanian novels before $1900^{13}$ is the presence of this new sensibility encoded aesthetically not as an obscure element, a curiosity, an eccentricity, but as a formative element, which demonstrates the modernity of the novel at a time of assimilation-fixation of the very genre in Romanian culture; at the time, the novelistic genre was still indebted to the romance, while tentatively fashioning itself into the novel proper, to use the terminology of novelistic history given currency by Paul Cornea in a seminal study ${ }^{14}$. The decadent novel became the turning-point of this change thanks to the

\footnotetext{
${ }^{13}$ Muzeul Digital al Literaturii Române [The Digital Museum of Romanian Literature], a project of Transilvania magazine, Sibiu, permits online search of all novels published by 1900: https://revistatransilvania.ro/mdrr. Furthermore, open access to all these novels is available thanks to another large-scale online project, the ELTeC: European Literary Text Collection (Distant Reading for European Literary History), set up on the Romanian side by Roxana Patraș:

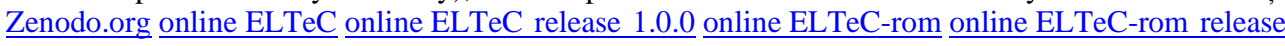
$\underline{0.7 .0}$

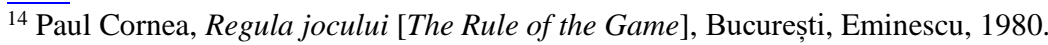


pre-eminently modern sensibility which it promoted, thus profoundly altering the familiar novelistic genre from the novel of manners, or the "social" novel.

At the end of the $19^{\text {th }}$-century, the novelistic genre in Romania included a number of romances and precious few novels; the writers stuck closely to their model through pastiche, as is the case of the novels of Const. I.A. Nottara, as well as of Ion Adam, if we go beyond the year 1900. Apart from the very few novels properly decadent, there were also novels such as those by Traian Demetrescu, which partook of this aesthetic sensibility at the level of style and character construction, yet without fully articulating decadent concerns. This is what Th. Cornel regarded, in Vlahuță's novel Dan, as "psychological finesse", where character psychology transgresses typology, in a process of individualisation characteristic of modernity as analysed by Matei Calinescu in his Five Faces of Modernity ${ }^{15}$.

Arguably, the fin-de-siècle Romanian novel evinces the same trait that David Weir, in Decadence and the Making of Modernism, has identified in European culture with respect to the relationship between decadence and Modernism. Investigating the difficulty of defining decadence, David Weir contends that the notion names not only a literary movement that never crystallised, never forged a conceptual form and an individuality through elimination of ambiguity, hence it is "a drama of unsettled aesthetics"; it also names an overall literary phenomenon, a part of modernity or, in Weir's own terms, "a dynamics of transition"16: "Decadence is transition, a drama of unsettled aesthetics, and the mixture of literary tendencies constituting that transition is at once within and without tradition and convention" 17 . In other words, we witness here a double move: one concerns the edification of a literary movement with its own aesthetics (its poetics), with its own representative authors and with its own corpus, especially large in French literature; the other concerns the edification of Modernism from Romanticism via decadence.

I have argued, in Decadență și decadentism in contextul modernității românești şi europene, that decadence is a mutagen insofar as it alters the aesthetic DNA of conceptually clearly identified literary movements such as Romanticism, Naturalism, Symbolism or, in the UK, Aestheticism (the Aesthetic Movement). I have also argued that decadent aesthetics permeates, among others, the modernist novel ${ }^{18}$. In fact, looking at the phenomenon from the perspective of subsequent

15 Matei Călinescu, Cinci fețe ale modernității. Modernism, avangardă, kitsch, decadență, Postmodernism [Five Faces of Modernity. Modernism, Avant-garde, Kitsch, Decadence, Postmodernism]. Translated by Tatiana Pătrulescu and Radu Țurcanu, Iași, Polirom, 2017.

${ }^{16}$ David Weir, Decadence and the Making of Modernism, Amherst, University of Massachusetts Press, 1996, p. 15

${ }^{17}$ Ibidem, p. 14.

${ }^{18}$ There are countless examples of postmodern novels which recycle elements of decadent aesthetics in the spirit of a literary game. A case in point in Romania is Mircea Cărtărescu. 
movements, we notice that the Avant-garde, not only Modernism, took up in part the decadent legacy, or rather integrated it within its own makeup, as Avant-garde theorist Renato Pogiolli ${ }^{19}$ argues, which is a way of fleshing out one of its own theses, namely its panaestheticism.

David Weir contends:

My position is that decadence is the common denominator underlying the extremely complex and diverse literary activities in the mid- to late nineeteenth century and that this substratum of decadence is crucial to the development of the modern novel ${ }^{20}$.

To state it otherwise:

.... number of literary movements and tendencies developed through decadence, either by reacting against its characteristic styles and terms, or by extending them in some way. The second point is that decadence itself developed as an independent movement at the same time that other, better known movements were developing through it. The dynamics of decadence as the medium of cultural transition between Romanticism and Modernism is complicated by this double movement ${ }^{21}$.

When he analyses the relationship between decadence and Modernism with respect to the novel, Weir gives the double example of James Joyce and André Gide $^{22}$. This is to say that there are novels which, far from being decadent thematically, are nevertheless permeated by a decadent sensibility, for instance through the maladive refinement of characters such that they themselves are sickly, through their aestheticism in deportment and affinities, through a culturally informed and deformed eroticism and the erudite cultivation of sensation, or through the inclusion within the horizon of existence of that of books which reflect the characters' decadent affinities. The two types of novel, the properly decadent one and the one with decadent affinities and modernist inclination, were produced by the Romanian writers first blazing the novelistic trail. What I have shown about the Romanian interwar nove ${ }^{23}$ was already manifestedly at work in this early stage of the edification of the novelistic genre in Romanian literature in the latter half of the $19^{\text {th }}$ century.

\footnotetext{
${ }^{19}$ Renato Poggioli, The Theory of the Avant-Garde. Translated from the Italian by Gerald Fitzgerald, Cambridge, Belknap Press/ Harvard University Press, 1968.

${ }^{20}$ David Weir, Decadence and the Making of Modernism, p. xvii.

${ }^{21}$ Ibidem, p. xix.

22 See the relationships between decadence and Romanticism especially in Flaubert's novel Salammbô, between decadence and Naturalism in the Goncourt brothers' novel Germinie Lacerteux, between decadence and aestheticism in Walter Pater's novel Marius the Epicurean, between decadence and décadisme, the movement started by Anatole Baju, in K.-J. Huysmans's novel $\grave{A}$ Rebours.

${ }^{23}$ See Angelo Mitchievici, Decadență și decadentism, pp. 498-585.
} 
Faces of Modernity: Suflete obosite [Exhausted Souls] and Intim [Intimate]

Suflete obosite, the novel of Const. I.A. Nottara, the one who compared himself to Octave Mirbeau, makes the model apparent, according to a contemporary of the author, the symbolist-decadent poet Dimitrie Karnabatt: "the novel oozed the influence of Huysmans, for its protagonist, an elevated spirit thanks to his hereditary exhaustion, resembled Des Esseintes in $\grave{A}$ Rebours"24. Decadent themes underpin this fin de l'époque novel, from its focus on the last scion of a prestigious aristocratic Byzantine family, Alexe Villara Comneanu, to the devitalisation, the "exhaustion" typical of the extinguishing of a family, from the erudition and aesthetic refinement of the family, the quintessence of its cultural-civilisational legacy, to the sterility and incapacity of investing all this genealogical capital. Individual decline parallels family decline, and the latter, in turn, reflects the larger decline of local aristocracy vis-à-vis the barbarism of upstart bourgeoisie, with its intreprid, transactional spirit honed for financial speculation, yet lacking intellectual finesse, fine manners, nobility and virtues. This kind of conflict would undergird Sadoveanu's prose writings and generally the texts written by authors associated with Sămănătorism, the early $20^{\text {th }}$-century literary-cultural movement that idealised the traditional village vis-à-vis the "corrupt" city. The decadent character, as this Byzantine-Wallachian des Esseintes is, is associated with a large library, often doubled by a pinacotheca, as in Huysmans's novel, whose selection criteria correspond to a particular taste, namely decadent sensibility. Alexe Villara Comneanu boasts such a library, which includes Huysmans, Flaubert with the novel Salammbô and the prose poem La tentation de Saint-Antoine, the Goncourt brothers with La Faustin, Paul Adam with Princesses Byzantines, as well as the complete works of Edgar Allan Poe and William Shakespeare. The family's pinacotheca includes Salvator Rosa, Tintoretto, Fuseli, Anibal Caraccio and Van Dyck, as well as a copy of Herodias et Salomé by Gustave Moreau, a painter affiliated with decadence both thematically and stylistically. Another character, the solicitor Zamfir Voilă, the virile-voluntary counterpart of the "exhausted" aristocratic protagonist, publishes, in French, a study on Nero, a fashionable subject for the Roman imperial decadence it evokes, and has the same book references as all decadent works - Baudelaire, Huysmans and Edgar Allan Poe:

His aesthetic observations on Nerone, compared to Beaudelaire (sic), Huysmans, Edgard Pöe (sic), in relation to all literary movements in France, had been lively debated in foreign magazines. Erotomaniac aesthetics, Neronism, Sapphism, the artistic life of Roman and Greek courtesans, the most important chapters of the aesthetic analysis by Zamfir Voilă, where the author had sought to establish the rapport between the orgiastic, artistic debauchery of ancient Rome and that of modern

${ }^{24}$ Dimitrie Karnabatt, Bohema de altădată [Bygone Bohemians], București, Vremea, 1944, pp. 194, 195. 
France, had kindled endless debate among the contributors to literary magazines in France and had made him famous abroad ${ }^{25}$.

That the novel mentions the character's study raises the topic to the level of literary ideas and the history of ideas, of debates current in the age, which sheds light on the cultural context within which the decadent novel is set.

Here too the exemplary Huysmans model is crucial, for the last scion of a family of Byzantine emperors caters to his tastes such that they establish a literary genealogy. In literature, such genealogy is rooted in a playwright recovered by the Romantics as their precursor, Shakespeare, via Edgar Allan Poe, in an already aesthetically mutant formula which blends the Gothic with a decadent sensibility, with a work by Flaubert which David Weir finds illustrative of how decadence altered the Romantic formula, and likewise with the aesthetically altered Naturalism of the Goncourt brothers. As regards painting, Gustave Moreau fully illustrates the decadent taste both thematically and stylistically, Henry Fuseli is the master of nightmarish supernatural themes, the baroque painter Salvator Rosa, a protoromantic, evokes a sensibility for ruin-strewn landscapes of stately devastation, and Van Dyck is famous for his portraiture, with dandy-looking aristocratic sitters. By depicting such closed-circuit libraries and pinacothecas, decadence set up its own tradition and genealogy, with its secret affinities, and thus related writers and painters belonging to different cultural ages. In effect, the cultural intertext is crucial for understanding a work whose decadence constitutes one of the "faces of modernity" as Matei Calinescu describes it. Like Huysmans' protagonist, with his interest in exotic horticulture and synaesthetic experiments, Alexe Villara Comneanu owns a greenhouse and manufactures his own scents, whose oneiric narcosis projects episodes of orgiastic Roman decadence, a favourite topic of fin-de-siècle decadent novels. Nottara's decadent novel features decadence as the bridge between Romanticism and Modernism. Yet, the praise of medievalism, with its outstanding historical personages and the romantic passion for the past, receives here a touch of alterity. Any interest expressed in generalizable ideality is doubled by an interest in the intimate life of the ancestors, the history of private life, the intimate detail, the anecdotal, the trivia and their own petite histoire, the kind of exotic details that Mateiu I. Caragiale's Agenda. Acta. Memoranda abounds in. Or, the protagonists of Roman decadence prefer precisely this kind of boudoir histories, with their spicy details and crude narratives, rather than heroism and patriotic devotion.

Intim, Traian Demetrescu's novella, sparked a lively polemic on its publication in 1892. Its novelty, like that of Vlahuță's novel Dan, was received with harsh criticism by many. The critic signing under the name Rion in Evenimentul literar [The Literary Event], for instance, started a debate on the problematic novelty of

${ }^{25}$ Const. I.A. Nottara, Suflete obosite [Exhausted Souls], Craiova, Institutul de Editură Ralian și Ignat Samitca, 1898, pp. 113-114. 
these texts; a year later, which indicates that the interest in Traian Demetrescu's novel was hardly dormant, E.D.F. associated the author, depreciatively, with the Parnasian poet and prolific decadent novelist Armand Sylvestre, hugely popular at the time ${ }^{26}$. Th. Cornel was rather reserved about Iubita [Beloved] (1895), an interesting sentimental novel, and mentioned no other novels by Demetrescu. Actually, the first challenge posed by Traian Demetrescu's novel is its diary format with its characteristic dated entries, which here span the period from 5 May to 5 July. A young man retires "within sublime Nature" - in the countryside - to partake of the melancholy of solitude, to return to his own interiority which provides him an opportunity for contemplation too. The novel best illustrates David Weir's thesis about the transition from Romanticism to modernity, with decadent sensibility as a go-between. The young man's sensibility appears to be romantic, for it follows the regressive drive in search for an idyllic micro-harmony, to use Virgil Nemoianu's notion. Nonetheless, there is something fundamentally different about the way in which the character lives his melancholy. The idyllic background is often transmogrified into a painting.

Furthermore, there is an active aesthetic consciousness which transcends romantic experience and thereby generates an aesthetic sublimation of the natural landscape as a manifest painterly or readerly reference. Even spontaneous emotion is converted into aesthetic emotion, although this occurs thanks to the vast referential potential of the work of art which bridges the reception of elements of nature, or, in other words, permanently processes landscape data as relevant only insofar as they correspond to a literary or painterly reference: "It's a painting: cattle moving slowly, heavily, followed by a peasant woman who displays her naked body under the moonshine. It is an idyll, a pastel of classical daintiness..."27; "I returned home gazing upwards to the sky the miserable Tasso loved so much and often described as skilfully as the brilliant Dante" ${ }^{28}$. Silence too evokes readerly references: "It's such a deep, perfect silence that you can hear the echo of a sigh, as the great Flaubert says so poetically" 29 and "inspires a sentimental education" - in other words, generates not ataraxy or elegiac remembrance, but an analytic drive. Nor is this technique of readerly or painterly associations occasional; rather, it becomes the rule, so that virtually every page includes at least one, if not two or more, such references. The moonshine is "like the touch of thin fingers, like a breeze 'that is blonde', as François Coppé would say"30; the human soul best unveils its nature through the work of art, of nature turned into an aesthetic artefact. Carl Maria von Weber's The Storm recalls "the nice, sickly figure" of the German

\footnotetext{
${ }^{26}$ E.D.F., "O tocmeală” [“A Bargain”], Evenimentul literar, 1894, 6.

27 Traian Demetrescu, Intim [Intimate]. Edited with an introduction by Ileana Manole, Craiova, Scrisul Românesc, 1983, p. 51.

${ }^{28}$ Ibidem, p. 53.

${ }^{29}$ Ibidem, pp. 47-48.

${ }^{30}$ Ibidem, p. 54.
} 
lady who had played it on the piano, unless the storm refers to Dostoevsky in straightforward fashion: "This storm still retains its evocative power, which the brilliant writings of Dostoevsky are filled with"31; alongside the consumption of spirits, smoking, which lulls awareness to sleep, evokes its condemnation by Tolstoy, as well as its defence by Dumas fils. Most readerly references include the romantics such as Mihai Eminescu, Heinrich Heine, Alfred de Musset (with his poem Nuit de décembre), Alfred de Vigny, Goethe (with his Die Leiden des jungen Werthers / The Sorrows of Young Werther) and Rousseau (with his Confessions), as well as Sully Prudhomme, the Parnasian of Romantic bent (whose Stances et Poèmes is often quoted in the diary entries), and writers whose works mark the transition from Romanticism to decadence, such as Edgar Allan Poe and Guy de Maupassant, or niche writers, like the very minor cabaret poet Raoul Ponchon (misspelled Raul Panchon), Edmond Haraucourt, the writer of "poèmes hysteriques", or the lustreless "Junimea" writer Theodor Șerbănescu.

Thus, the young man puts up the airs of the member of a decadent family when he declares himself, if in interrogative format, as blasé: "Could I have been born blasé, "with my soul wounded'?"32. Anyway, his analytic spirit works in tandem with a sense of defeat, of detachment: "Of course: this analysis is much too personal to yield to generalisation. Yet, what if it sums up the psychology of isolated cases which make up the family of those vanquished early?"33. The only decidedly decadent episode concerns the fleeting affair with a Danish woman who has all the characteristic traits of a femme fatale: she flaunts the perverse, sickly namely, hysterical and culturally informed - eroticism symptomatic of incipient modernity. The Danish erotomaniac is also a collector of rare scents, which she "breathes in with a sickly voluptuousness"34; she likes spirits, which intoxicate her senses with an intensity that evokes the "artificial paradises" of the opiates and of Baudelaire: "They give her a bizarre voluptuousness, which engenders lubricious ecstasy or something akin to the slumber of drinkers of hashish" 35 . "Bizarreness", "refinement", "hysteria", "mysticism" and "vice" are traits that at the time belonged to the aesthetic code of decadence, all the more so as they were circumscribed by eroticism: "From mad kissing she suddenly switches to bitter disgust; at other times she speaks about mystical love. And in between the caresses of a refined woman and hysterical, brutal spasms, she recounts her adolescence an awfully vicious adolescence" 36 . The protagonist undertakes his sentimental education with Antoine François Prévost's Manon Lescaut, another emblematic novel recovered by decadent tradition, first read during his undergraduate studies,

\footnotetext{
${ }^{31}$ Ibidem.

32 Ibidem, p. 39.

${ }^{33}$ Ibidem.

${ }^{34}$ Ibidem, p. 31

35 Ibidem.

${ }^{36}$ Ibidem, p. 32.
} 
from which he learns the following word of wisdom: "To a certain extent, every man is a 'des Grieux' and every woman a 'Manon Lescaut"'37.

The novelty concerns psychologising illness in relation to eroticism as perversion, via Baudelairean decadence, as Mario Praz aptly puts it: "It was the Romantics, profiting from the theories of the Divine Marquis, and especially of Baudelaire, who gave a psychological turn to the refinements of perversity" ${ }^{38}$. The author of La carne, la morte e il diavolo nella letteratura romantica regards decadence as crepuscular Romanticism whose erotic sensibility bears the impression of the Divine Marquis - in other words, he suggests this transition from Romanticism to Modernism via decadence which the fin-de-siècle Romanian novel also illustrates.

\section{BIBLIOGRAPHY}

CALINESCU, Matei, Cinci fețe ale modernității. Modernism, avangardă, kitsch, decadență, postmodernism [Five Faces of Modernity. Modernism, Avant-garde, Kitsch, Decadence, Postmodernism]. Translated by Tatiana Pătrulescu and Radu Țurcanu, Iași, Polirom, 2017.

CORNEA, Paul, Regula jocului [The Rule of the Game], București, Eminescu, 1980.

CORNEL, Th., La Roumanie littéraire d'aujourd'hui, Paris, E. Sansot et Cie 1903.

DEMETRESCU, Traian, Intim [Intimate]. Edited with an introduction by Ileana Manole, Craiova, Scrisul Românesc, 1983.

ELIADE, Pompiliu, Influenţa franceză asupra spiritului public în România. Originile. Studiu asupra stării societăţii româneşti în vremea domniilor fanariote [The French Influence on the Public Spirit in Romania - the Origins: A Study of the Condition of Romanian Society under the Phanariot Rulers], București, Editura Institului Cultural Român, 2006.

KARNABATT, Dimitrie, Bohema de altădată [Bygone Bohemians], București, Vremea, 1944.

KRAFFT-EBING, Richard, Psychopathia Sexualis. Translated by René Lobstein. Preface by Pierre Janet, Paris, Payot, 1931.

MAIORESCU, Titu, Critice [Critical Studies], București - Chișinău, Litera, [s.a.].

MITCHIEVICI, Angelo, Decadență și decadentism în contextul modernității românești și europene [Decadence and Decadentism within Romanian and European Modernity], București, CurteaVeche, 2011.

NOTTARA, Const. I.A., Suflete obosite [Exhausted Souls], Craiova, Institutul de Editură Ralian și Ignat Samitca, 1898.

POGGIOLI, Renato, The Theory of the Avant-Garde. Translated from the Italian by Gerald Fitzgerald, Cambridge, Belknap Press/ Harvard University Press, 1968.

PALACIO, Jean, Figures et formes de la décadence, Paris, Séguier, 1994.

PATRAȘ, Roxana, "Hajduk Novels in Nineteenth-Century Romanian Culture: Notes on a SubGenre", Swedish Journal of Romanian Studies, 2, 2019, 1 , http://www.diacronia.ro/ro/indexing/details/A30120/pdf.

PRAZ, Mario, The Romantic Agony. Translated from the Italian by Angus Davidson, New York, Meridian Books, 1956.

WEIR, David, Decadence and the Making of Modernism, Amherst, University of Massachusetts Press, 1996.

${ }^{37}$ Ibidem, pp. 40-41.

${ }^{38}$ Mario Praz, The Romantic Agony. Translated from the Italian by Angus Davidson, New York, Meridian Books, 1956, p. 106. 


\title{
THE POSITION OF THE DECADENT NOVEL WITHIN ROMANIAN FIN-DE- SIÈCLE LITERATURE \\ (Abstract)
}

My approach considers the beginnings of establishing the novel as a literary genre in the context of Romanian literature and the critical reviews of the new genre and its specialization in a series of relevant subgenres from the novel with outlaws (Hajduks) to the decadent novel. We followed the evolution of the latter at the end of the 19th century and the growth of the first germs of modernity. Relying on David Weir's theory in Decadence and the Making of Modernism that decadentism is "a dynamics of transition" to Avant-garde and modernity and the mutagenic character of decadentism highlighted by many theorists from Marion Praz and A.E. Carter to Koenraad W. Swart and Renato Poggioli, I envisaged two case studies. In this regard, we analyzed by comparison the novel Exhausted Souls (1893) by Const. I.A. Notarra, partly a pastiche after a decadent-model novel, $\grave{A}$ rebours by K.-J. Huysmans, and the novel Intimate (1892) by Traian Demetrescu to underline this transition to modernity beyond common themes and an aestheticizing perspective on emotions.

Keywords: novel, decadence, modernism, fin de siècle, sensibility.

\section{POZIȚIA ROMANULUI DECADENT ÎN CADRUL LITERATURII ROMÂNE FIN-DE-SIËCLE (Rezumat)}

\begin{abstract}
Abordarea mea are în vedere începuturile constituirii romanului ca gen literar în contextul literaturii române și al receptării critice a noului gen și specializarea acestuia într-o serie de subgenuri relevante de la romanul cu haiduci la romanul decadent. Am urmărit evoluția acestuia din urmă la sfârșitul secolului XIX și apariția primilor germeni ai modernității. Bazându-mă pe teoria lui David Weir din Decadence and the Making of Modernism cum că decadentismul reprezintă „o dinamică a tranziției” către avangarde și modernitate și pe caracterul mutagen al decadentismului evidențiat de numeroși teoreticieni de la Marion Praz și A.E. Carter la Koenraad W. Swart și Renato Poggioli, mi-am propus două studii de caz. În acest sens, am analizat prin comparație romanul Suflete obosite (1893) al lui Const. I.A. Notarra, în parte o pastișă după un roman decadent-model, À rebours al lui K.-J. Huysmans, și romanul Intim (1892) al lui Traian Demetrescu pentru a evidenţia această tranziţie către modernitate dincolo de temele comune și de o perspectivă estetizantă asupra emoțiilor.
\end{abstract}

Cuvinte-cheie: roman, decadență, modernism, fin de siècle, sensibilitate. 